\title{
Perancangan Sistem Informasi Untuk Perawatan Dan Perbaikan Modul Pratikum Berbasis Web
}

\author{
Anggara Nasution1, Raemon Syaljumairi ${ }^{2 *}$, Rusfandi ${ }^{3}$ \\ 1,3 Jurusan Teknik Elektro, Politeknik Negeri Padang \\ ${ }^{2}$ Jurusan Teknologi Informasi, Politeknik Negeri Padang \\ anggara@pnp.ac.id \\ Kampus Politeknik Negeri Padang, Limau Manis Padang
}

\begin{abstract}
Microprocessor and microcontroller laboratories are type III laboratories that are in the electronics engineering study program majoring in electrical engineering, this laboratory serves the activities of student practices for microprocessor system courses, microcontroller systems and interfaces I and II and very large scale intergration (VLSI) programmable logic devices and programmable electronics. Laboran as manager and person in charge of the laboratory, every month submits reports on equipment support facilities and practice modules made manually to the head of the laboratory. Every day the laboratory staff must examine all equipment activities one by one such as computers and practice modules to find out the latest conditions. Seeing the problems above, we need a system solution that can provide fast, accurate, complete and integrated information as a whole. The purpose of this study is to produce an information system design for maintenance and repairs to microprocessor and microcontroller laboratories. The method used in this study analyzes the current system to create a conceptual model so as to produce a database diagram. Next, the design of the display includes the design of the application interface such as the reporter display, laboratory performance reports etc. To further maximize laboratory use and quality teaching and learning is expected that students, lecturers and staff will also participate by reporting damage to supporting facilities at the microprocessor and microcontroller laboratory.
\end{abstract}

Keywords: damage reports, information systems, maintenance, repairs.

\begin{abstract}
Abstrak-Laboratorium mikroprosesor dan mikrokontroler merupakan laboratorium tipe III yang berada pada program studi teknik elektronika jurusan teknik elektro, laboratorium ini melayani kegiatan pratikum mahasiswa untuk mata kuliah sistim mikroprosesor, sistem mikrokontroler dan interfacing I dan II serta programmable logic device very large scale intergration (VLSI) dan elektronika terprogram. Laboran sebagai pengelola dan penanggung jawab laboratorium, setiap bulannya menyerahkan laporan fasilitas penunjang peralatan dan modul pratikum yang dibuat secara manual kepada kepala laboratorium. Setiap harinya laboran harus memeriksa keseluruhan peralatan kegiatan pratikum satu persatu seperti komputer dan modul pratikum untuk mengetahui kondisi terkini. Melihat permasalahan di atas maka diperlukan suatu solusi sistem yang dapat menyediakan informasi yang cepat, akurat, lengkap dan terintegrasi secara keseluruhan Tujuan penelitian ini adalah menghasilkan rancangan sistim informasi untuk perawatan dan perbaikan pada laboratorium mikroprosesor dan mikrokontroler. Metode yang digunakan pada penelitian ini menganalisa sistim yang sedang berjalan saat ini untuk membuat model konseptual sehingga menghasilkan diagram basis data (database).Selanjutnya perancangan tampilan yang meliputi rancangan antarmuka aplikasi seperti tampilan pelapor, laporan kinerja laboran dll.Untuk semakin memaksimalkan penggunaan laboratorium serta kualitas belajar mengajar diharapkan mahasiswa, dosen dan staff ikut berperan serta dengan ikut melaporkan kerusakan pada fasilitas penunjang dilaboratorium mikroprosesor dan mikrokontroller.
\end{abstract}

Kata kunci: laporan kerusakan,sistem informasi, perawatan, perbaikan

(c) 2018Elektron Jurnal Ilmiah

\section{PENDAHULUAN}

Perkembangan ilmu pengetahuan dan teknologi yang semakin maju menuntut penyelenggaraan laboratorium yang berkualitas, baik dari sumber daya manusia maupun fasilitas penujang kegiatan praktikum mahasiswa, Laboratorium Mikroprosesor dan Mikrokontroler (MC) merupakan laboratorium kategori 3 yang berada pada program studi teknik elektronika jurusan teknik elektro, laboratorium ini melayani kegiatan pratikum mahasiswa untuk mata kuliah sistim mikroprosesor, sistem mikrokontroller dan interfacing I dan II serta PALS VLSI dan elektronika terprogram [1][2].Selain berfungsi sebagai laboratorium pendidikan, laboratorium ini juga berfungsi melayani kegiatan penelitian dan tugas akhir. Laboratorium mikroprosesor dan mikrokontroller memiliki satu laboran untuk membantu kepala laboratorium dalam melayani dosen, peneliti maupun mahasiswa. Berikut tabel kegiatan pratikum pada laboratorium mikroprosesor dan mikrokontroller. 
Tabel 1 Kegiatan Pratikum Pada Laboratorium Mikroprosesor dan Mikrokontroller

\begin{tabular}{|c|c|c|c|c|}
\hline $\begin{array}{l}\mathrm{N} \\
\mathrm{o}\end{array}$ & $\begin{array}{l}\text { Kegiatan } \\
\text { Pratikum }\end{array}$ & $\begin{array}{c}\text { Alat } \\
\text { Pratikum }\end{array}$ & $\begin{array}{c}\text { Alat } \\
\text { Penunjang }\end{array}$ & $\begin{array}{c}\text { Program } \\
\text { Studi }\end{array}$ \\
\hline 1 & $\begin{array}{l}\text { Sisem } \\
\text { Mikroprosesor }\end{array}$ & $\begin{array}{l}\text { Modul } \\
\text { Z-80 }\end{array}$ & Komputer & $\begin{array}{l}\text { D3, D4 } \\
\text { Teknik } \\
\text { Elektronika }\end{array}$ \\
\hline 2 & $\begin{array}{l}\text { Sistem } \\
\text { Mikrokontroller } \\
\text { dan Interfacing } \\
1,2\end{array}$ & $\begin{array}{l}\text { Modul } \\
\text { Mikrokon } \\
\text { troller } \\
\text { AT89S51, } \\
\text { Modul } \\
\text { AVR } \\
\end{array}$ & Komputer & $\begin{array}{l}\text { D3, D4 } \\
\text { Teknik } \\
\text { Elektronika } \\
\text { D3 Teknik } \\
\text { Komputer }\end{array}$ \\
\hline 3 & $\begin{array}{l}\text { PALS VLSI dan } \\
\text { Elektronika } \\
\text { Terprogram }\end{array}$ & $\begin{array}{l}\text { Modul } \\
\text { PALS } \\
\text { VLSI } \\
\end{array}$ & Komputer & $\begin{array}{l}\text { D3, D4 } \\
\text { Teknik } \\
\text { Elektronika }\end{array}$ \\
\hline
\end{tabular}

Dari tabel 1 dapat dilihat setiap kegiatan pratikum menggunakan alat pratikum berupa modul pratikum dan komputer sebagai alat penunjang kegiatan pratikum, dan dari tabel 1 juga dapat dilihat kegiatan pratikum di laboratorium digunakan oleh tiga program studi (D3 teknik elektronika, D4 teknik elektronika dan D3 teknik komputer) sehingga dapat disimpulkan intensitas pemakaian laboratorium ini cukup tinggi, akibatnya tentu saja berdampak pada penggunaan fasilitas laboratorium seperti modul pratikum dan komputer yang dapat mengalami kerusakan sehingga dapat menggangu kegiatan pratikum, Untuk mengantisipasi hal tersebut dibutuhkan kegiatan perawatan dan perbaikan [3][4]. Berikut tabel data perawatan dan perbaikan di laboratorium mikroprosesor dan mikrokontroller yang diambil dari logbook tahun akademik 2015/2016 dan 2017/2018.

Tabel 2. Jumlah Perbaikan modul

\begin{tabular}{|c|c|c|c|}
\hline \multirow[b]{2}{*}{$\begin{array}{c}\text { Tahun } \\
\text { Akademik }\end{array}$} & \multirow[b]{2}{*}{ Alat Pratikum } & \multicolumn{2}{|c|}{ Perbaikan } \\
\hline & & Service & $\begin{array}{l}\text { Ganti } \\
\text { Part }\end{array}$ \\
\hline \multirow{5}{*}{$2015-2016$} & $\begin{array}{c}\text { MODUL MCS- } \\
\text { AT89S51 }\end{array}$ & 35 & 38 \\
\hline & MODUL AVR & 31 & 27 \\
\hline & $\begin{array}{c}\text { MODUL PALS } \\
\text { VLSI }\end{array}$ & 24 & 28 \\
\hline & MODUL Z-80 & 21 & 13 \\
\hline & KOMPUTER & 65 & 17 \\
\hline $\begin{array}{c}\text { Total } \\
\text { Kerusakan }\end{array}$ & 299 & 176 & 123 \\
\hline \multirow{5}{*}{$2017-2018$} & $\begin{array}{c}\text { MODUL MCS- } \\
\text { AT89S51 }\end{array}$ & 28 & 30 \\
\hline & MODUL AVR & 25 & 23 \\
\hline & $\begin{array}{c}\text { MODUL PALS } \\
\text { VLSI }\end{array}$ & 20 & 22 \\
\hline & MODUL Z-80 & 25 & 14 \\
\hline & KOMPUTER & 70 & 22 \\
\hline $\begin{array}{c}\text { Total } \\
\text { Kerusakan } \\
\end{array}$ & 279 & 168 & 111 \\
\hline
\end{tabular}

Dari tabel 2 dapat dilihat pada tahun akademik 2015/2016 kerusakan modul pratikum dan komputer total berjumlah 298 dengan perincian modul pratikum sebanyak 216 dan komputer 82. Pada tahun akademik 2017/2018 kerusakan pada modul pratikum mengalami penurunan menjadi 276 atau 7,38\% dari tahun sebelumnya, hal itu dikarenakan dibuatnya rangkaian simulasi untuk modul pratikum, jadi mahasiswa dapat mensimulasikan hasil pratikum mereka ke rangkaian simulasi sebelum ke modul pratikum sehingga hal ini dapat meminimalisir kerusakan pada modul. Dari tabel di atas juga dapat dilihat kerusakan pada komputer mengalami peningkatan sebesar 8,53\%. Setelah dilakukan analisa, yang menyebabkan terjadinya peningkatan kerusakan baik modul pratikum maupun komputer yaitu

a) Kesulitan dalam pendokumentasian penanganan modul pratikum dan computer yang ada seperti yang diperbaiki bagian apa dan perangkat keras apa yang digunakan

b) Penanganan kerusakan lambat karena kurangnya informasi kerusakan peralatan yang ada dan minimnya informasi jumlah spare part yang ada

c) Kurangnya informasi tentang kondisi laboratorium secara global yang dapat digunakan dalam pengambilan keputusan

Melihat permasalahan di atas maka diperlukan suatu solusi sistem yang dapat menyediakan informasi yang cepat, akurat, lengkap dan terintegrasi secara keseluruhan. Perancangan sistem informasi perawatan dan perbaikan berbasis web pada laboratorium mikroprosesor dan mikrokontroller berguna untuk mengetahui kondisi modul pratikum dan computer sehingga dapat membantu teknisi atau laboran meminimalisir kerusakan. peralatan pratikum, dan bagi kepala laboratorium dapat mengetahui kondisi peralatan pratikum laboratorium keseluruhan secara berkala sedangkan bagi user/pengguna dapat melaporkan kerusakan langsung kepada teknisi/laboran.Penelitian yang terkait sebelumnya pernah dilakukan oleh [5], yang berjudul Penerapan Zachman Framework Dalam Merancang Sistem Pelaporan Kerusakan Komputer, dalam penelitiannya andika dkk menggunakan konsep zachman dan framework zachman dalam perancangan sistem, selain itu objek penelitian ini hanya pada kerusakan computer.Selain itu penelitian terkait juga pernah dilakukan oleh [6], yang berjudul Perancangan Sistem E-Ticketing Lab Komputer, dalam penelitiannya andi dkk menerapkan konsep e-ticketing dalam pelaporan kerusakan komputer, begitu juga dengan [7][8] sama halnya dengan andika dkk objek penelitian hanya pada kerusakan komputer.

\section{Metode Penelitian}

Dalam Penelitian ini, terdapat beberapa tahapan yang harus dilakukan untuk pencapaian hasil yang maksimal. Tahapannya sebagai berikut ini :

1. Analisa

Menganalisa ruang lingkup permasalahan pelaporan, perbaikan komputer,modul pratikum dan pengontrolan kinerja laboran, sehingga dapat diketahui apa yang dibutuhkan sistem aplikasi 
yang dirancang. Spesifikasi yang dibutuhkan meliputi: Fungsi (memberikan gambaran prosedur aplikasi), Tingkah laku (memberikan gambaran kebutuhan dan keinginan klien), Kinerja (memberikan gambaran kemampuan aplikasi), dan Antarmuka (mengambarkan kebutuhan klien terhadap antarmuka).

2. Design

Berdasarkan spesifikasi kebutuhan yang sudah didefenisikan, dapat dilakukan perancangan sistem aplikasi ini meliputi: konsep aplikasi, rancangan basis data, diagram aktifitas dan rancangan antarmuka aplikasi.

\section{Hasil dan Pembahasan}

\section{A. Model Konseptual dan Basis Data}

Laboratorium mikroprosesor dan mikrokontroller memiliki satu laboran untuk membantu kepala laboratorium dalam melayani dosen, peneliti maupun mahasiswa Sistem perawatan dan perbaikan yang berjalan di laboratorium ini ada dua proses, yang pertama sebelum dilaksanakan kegiatan pratikum yang kedua ketika kegiatan pratikum dilaksanakan

Sebelum pratikum dilaksanakan

1. Sebelum pratikum dimulai, laboran melakukan pengecekan terhadap modul pratikum dan komputer

2. Jika ada kerusakan baik pada modul pratikum maupun komputer laboran akan melakukan perbaikan, peralatan yang rusak dicatat dalam logbook perbaikan

3. Informasi hasil perbaikan, baik yang berhasil diperbaiki maupun yang tidak, serta spare part apa yang digunakan kemudian kategori perbaikan, apakah service maupun ganti part dicatat di logbook perbaikan.

4. Setiap bulan teknisi membuat laporan kepada kepala laboratorium tentang perawatan dan perbaikan di laboratorium

Pratikum dilaksanakan

1. Teknisi akan melakukan pegawasan pada waktu pratikum dilaksanakan, jika ada laporan kerusakan baik dari mahasiswa maupun dari dosen yang mengajar teknisi akan melakukan pengecekan.

2. Jika ada kerusakan baik pada modul pratikum maupun komputer teknisi akan melakukan perbaikan, peralatan yang rusak dicatat dalam logbook perbaikan

3. Informasi hasil perbaikan, baik yang berhasil diperbaiki maupun yang tidak, serta spare part apa yang digunakan kemudian kategori perbaikan, apakah service maupun ganti part dicatat di logbook perbaikan.

4. Setiap bulan teknisi membuat laporan kepada kepala laboratorium tentang perawatan dan perbaikan di laboratorium
Laboran memerlukan banyak waktu untuk melaksanakan tugasnya, karena kerusakan yang terjadi tidak langsung diketahui, tetapi dengan memeriksa satu persatu komputer dan modul pratikum yang ada. Hal ini juga berakibat pada kegiatan belajar mengajar, karena beberapa unit komputer dan modul pratikum tidak dapat digunakan sebagaimana mestinya.

Demikian juga terhadap dosen, mahasiswa dan staff jika menemukan masalah pada salah satu komputer maupun modul pratikum harus menemui laboran atau kepala lab terlebih dahulu untuk melaporkan masalah tersebut. Sedangkan kepala lab harus menunggu diberikan laporan tentang laboratorium mikroprosesor dan mikrokontroler oleh laboran terlebih dahulu untuk dapat mengetahui keadaan laboratorium tersebut. Oleh sebab itulah dibutuhkan sebuah sistem yang dapat membantu pelapor untuk melaporkan kerusakan yang terjadi, laboran untuk segera mungkin menindak lanjuti laporan pelapor dan memperbaiki komputer atau modul pratikum yang rusak, serta kepala lab untuk dengan cepat dapat melihat laporan laboratorium mikroprosesor dan mikrokontroler. Berikut ini merupakan gambar dari model konseptual sistem yang akan dibuat.

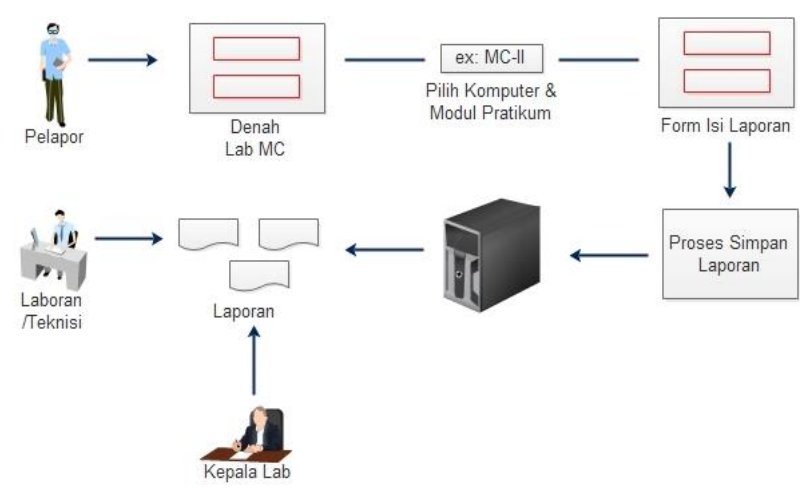

Gambar 1 Model Konseptual

Pada model konseptual diatas, pelapor dapat melaporkan kerusakan komputer maupun modul pratikum yang ditemukan dengan mengakses website sistem perawatan dan perbaikan. Pelapor dapat melaporkan kerusakan dengan mengisi form kerusakan komputer maupun modul pratikum. Laporan ini nantinya dapat dilihat oleh laboran dankepala lab yang kemudian dapat ditindak lanjuti. Berikut ini merupakan gambar dari relasi tabel dalam basis data sistem perawatan dan perbaikan laboratorium MC. 


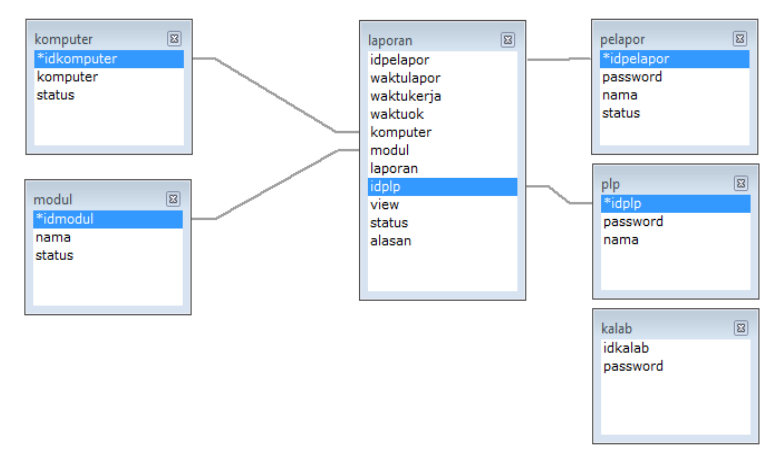

Gambar 2 Diagram Basis Data

Tampilan awal dari sistem ini merupakan sebuah halaman utama yang mewajibkan penggunanya untuk menginput username dan password. Gambar 3 adalah tampilannya.

\begin{tabular}{|l|l|l|}
\hline LOGIN PELAPOR \\
\hline Silahkan Masukan ID Pelapor dan Password Anda \\
\hline ID Pelapor : & \\
\hline Password : & \\
\hline & & \\
\hline
\end{tabular}

Gambar 3 Login Pelapor

Setelah username dan password diisikan dengan benar maka akan tampil sebuah form menu untuk pelapor seperti tampilan gambar 4 .

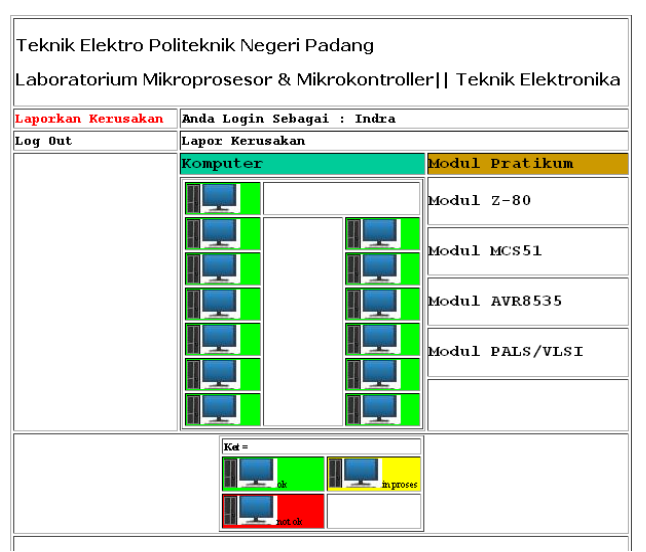

Gambar 4 Form laporan kerusakan

Pada tampilan ini, pelapor cukup mengklik menu tersedia yaitu komputer atau modul pratikum. Pada menu komputer, tampilan berupa gambar denah kondisi lab terkini, setiap gambar yang ada merupakan sebuah link yang dapat diklik. Ketika ada komputer yang rusak pelapor cukup mengklik komputer yang berwarna hijau lalu memasukkan berita acara laporannya pada form isi. Selain dari menu komputer terdapat juga menu modul pratikum, pada menu pratikum pelapor dapat memilih modul pratikum apa yang mengalami kerusakan, pelapor dapat juga memasukkan berita acara laporannya pada form isi laporan seperti gambar 5 .

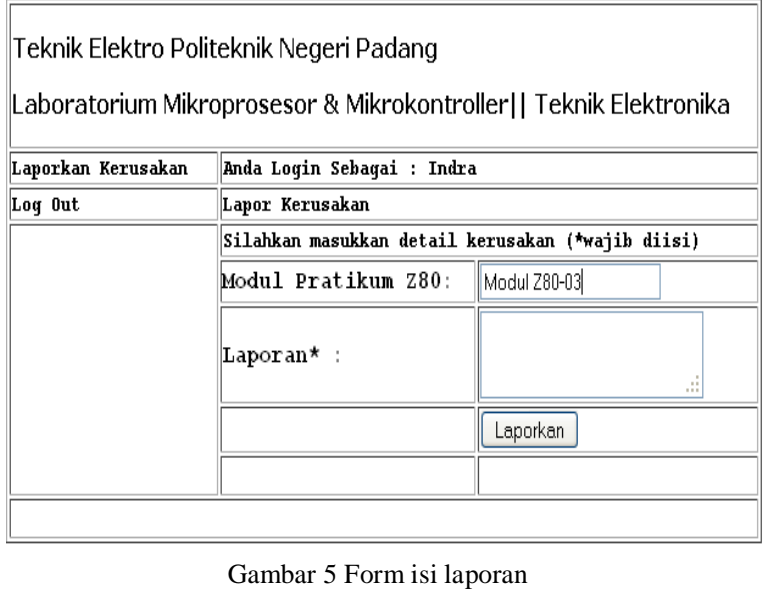

Selanjutnya adalah tampilan dari laboran/Teknisi, Pada menu dan form dari laboran menampilkan laporan dari pelapor pada menu sebelumnya, sehingga laboran dapat mengetahui permasalahan yang terdapat pada lab. Laporan yang diterima pada form laboran adalah sebagai berikut. Pada gambar 6 merupakan form notifikasi dari laporan yang dilakukan oleh pelapor mengenai kerusakan komputer maupun modul pratikum, dalam form ini laboran dapat melihat laporan terbaru. Laporan dibagi menjadi dua yaitu laporan yang masih baru dan laporan yang sudah diproses, laporan yang masih baru adalah laporan yang masih belum dikerjakan oleh laboran, dan laporan sudah proses merupakan laporan yang sudah dikerjakan oleh laboran baik yang sudah benar maupun yang belum selesai

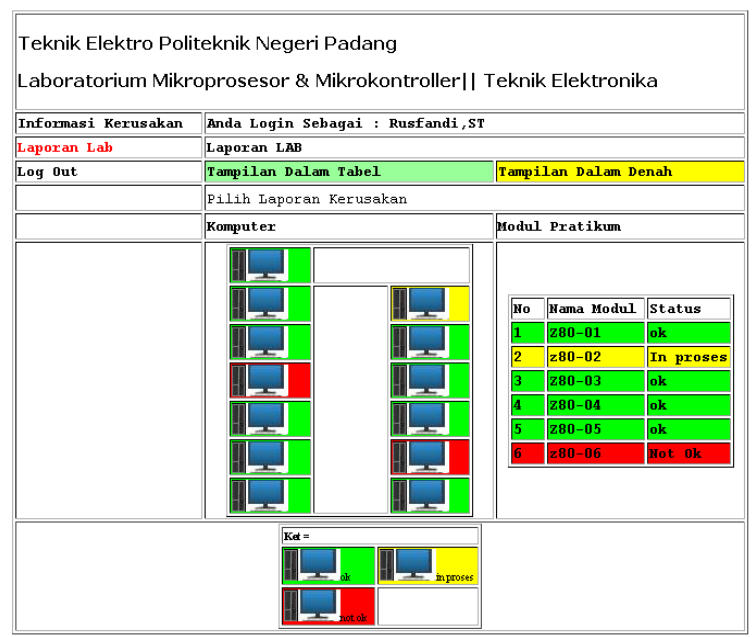

Gambar 6 Form notifikasi laporan 
Berikutnya form untuk melihat laporan berdasarkan denah dan tabel. Laporan berdasarkan denah akan menampilkan posisi komputer yang terdapat pada ruang lab MC. Dari denah tersebut laboran dapat melihat jajaran komputer yang berwarna, masing-masing warna memiliki arti merah artinya komputer dalam keadaan rusak dan warna merah ini terjadi karena adanya laporan bahwa komputer tersebut rusak, warna kuning menandakan bahwa komputer tersebut masih dalam perbaikan oleh laboran, dan terakhir berwarna hijau warna ini merupakan warna dimana komputer dalam keadaan baik.Sedangkan laporan berbentuk tabel menampilkan kerusakan pada modul pratikum masing-masing warna memiliki arti yang sama pada kerusakan komputer. Berikut ini tampilan form laporan denah dan laporan tabel

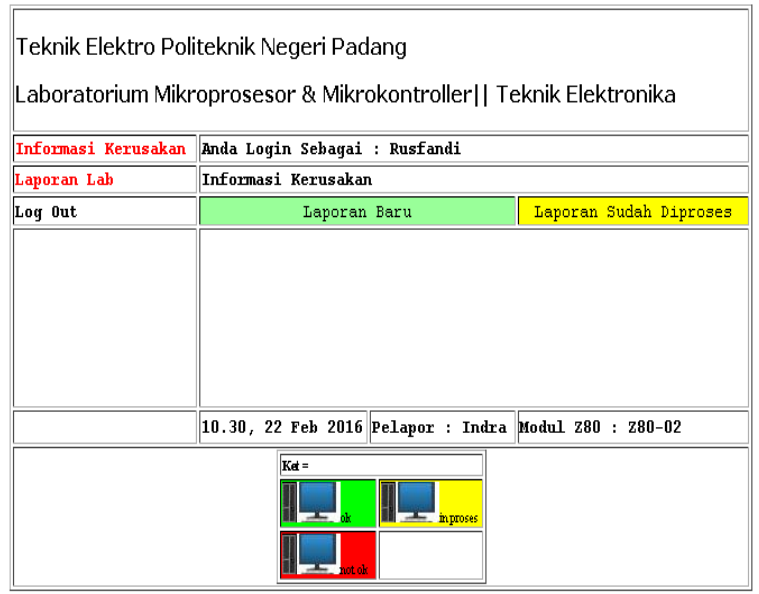

Gambar 7 Laporan lab dengan denah dan tabel

Selain laboran dapat melihat laporan kerusakan pada lab MC kepala lab juga dapat melihat notifikasi dan kondisi laporan denah ruang lab sama seperti halnya laboran, namun ada beberapa perbedaan yaitu laporan lab berdasarkan tanggal dan laporan kinerja laboran. Berikut ini merupakan tampilan dari laporan kinerja laboran.

\begin{tabular}{|c|c|c|c|c|c|c|}
\hline \multicolumn{7}{|c|}{$\begin{array}{l}\text { Teknik Elektro Politeknik Negeri Padang } \\
\text { Laboratorium Mikroprosesor \& Mikrokontroller|| Teknik Elektronik }\end{array}$} \\
\hline Laporan PLP & \multicolumn{6}{|c|}{ Bnda Loyin Sebayai： Andrizal, SI, UIT } \\
\hline Laporan Lab & \multicolumn{6}{|c|}{ Laporan Kinerja PLP } \\
\hline \multirow[t]{6}{*}{ Log out } & & & & & & \\
\hline & \multicolumn{6}{|c|}{ Laporan PLP Lab.llikroprosesor \& Mlikrokontroller || Teknik Elektronika } \\
\hline & Mo & Iana PLP & Komputer & \begin{tabular}{|l|l} 
Modul \\
Pratikum
\end{tabular} & \begin{tabular}{|l|l} 
Junlah \\
Perbaikan
\end{tabular} & \begin{tabular}{|l} 
Dalam \\
Pengerjaan
\end{tabular} \\
\hline & 1 & Rusfandi & & 4 & 7 & 1 \\
\hline & 2 & Anggara & & 1 & 2 & 2 \\
\hline & Total & & 4 & 5 & 9 & 3 \\
\hline
\end{tabular}

Gambar 8 Laporan kinerja Laboran
Berikutnya adalah gambar 9 merupakan tampilan dari laporan berdasarkan tanggal perhari, perbulan bahkan pertahun.

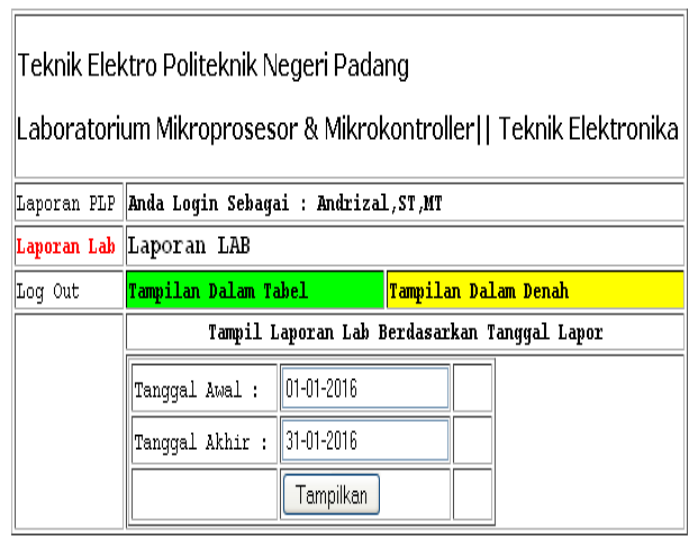

Gambar 9 Laporan berdasarkan tanggal

dan selanjutnya pada gambar 10 merupakan tampilan dari hasil kinerja laboran perhari atau perbulan bahkan pertahun dari apa yang sudah dikerjakan oleh laboran

\begin{tabular}{|c|c|c|c|c|c|c|c|c|}
\hline \multicolumn{9}{|c|}{ LAPORAI LAB MIKROPROSBSOR \& UITROOKOHTROLLER I| } \\
\hline \multicolumn{9}{|c|}{ 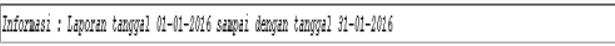 } \\
\hline Io Pelaport:ąor & $\overline{D i p e r b a i k i}$ & \begin{tabular}{|l} 
Selessi \\
Diperbaiki
\end{tabular} & Rouputer & Protil & Laporan & $\begin{array}{l}\text { Diperbiaki } \\
\text { Oled }\end{array}$ & Status & Ret \\
\hline 1. Inira \begin{tabular}{l|l}
03 Jan \\
2016
\end{tabular} & 03 Ven 2016 & & Rouplter-01 & & Do pover & inygara & Diperbaiki & \\
\hline 2 sporyan 25 van & $05 \mathrm{ven} 2016$ & & & $200-10$ & Do Pover & Rusfandi & Diperbaiki & \\
\hline
\end{tabular}

Gambar 10 Laporan berdasarkan tanggal

\section{KESIMPULAN}

Dari proses analisa dan perancangan sistem informasi perawatan dan perbaikan ini dapat diambil beberapa kesimpulan yaitu, dapat mengakomodir laporan kerusakan baik komputer dan modul pratikum di laboratorium MC. Kepala laboratorium dapat memantau kinerja laboran setiap waktunya dan laporan tahunan dapat diperoleh tanpa harus menunggu laporan dari laboran.

\section{REFENSI}

[1] Pembuatan Simulasi rangkaian modul pratikum mikrokontroller at89s51 untuk meminimalisir kerusakan modul pratikum, Seminar Nasional Informatic Event (SNIVENT 2014), Jakarta, 02 Desember 2014

[2] Anggara Nasution, Rusfandi (2015), Desain dan Penerapan Simulasi rangkaian programmable logic device pada pratikum vlsi dan elektronika terprogram, Seminar Nasional Pengelolaan 
Laboratorium Pendidikan Universitas Sunan Kalijaga, Yogyakarta, 10 Oktober 2015

[3] Ebeling, Charles E (1997), An Introduction to Realibility and Maintainability Engineering. McGraw-Hill International Edition

[4] Al-Turki, U.2001, A Framework for Strategic Planning in Maintanance, Journal of Quality in Maintanance Engineering, Vol.17, No.2, pp 150-162

[5] Andi Nugroho, Ririn rizkawati A, Achmad (2014), Perancangan Sistem E- Ticketing Lab Komputer STTI I-TECH Jakarta
Berbasis Web Menggunakan PHP dan MySql, Seminar Nasional Informatic Event (SNIVENT 2014), Jakarta, 02 Desember 2014

[6] Nency Extise Putri. (2016). Sistem Pakar Kerusakan Hardware Komputer Dengan Metode Forward Chaining. Jurnal Momentum Vol.18 No.2 Agustus 2016

[7] Januar Lestari. (2016). Analisis Sistem Deteksi Kerusakan Komputer Dengan Menggunakan Metode Forward Chaining. Jurnal Inspiraton, Volume 6, Nomor 1, Juni 2016: 19 - 27 